\title{
顎変形症治療の歴史と現状，今後の課題 The surgical treatment of the jaw deformities, past, present and future
}

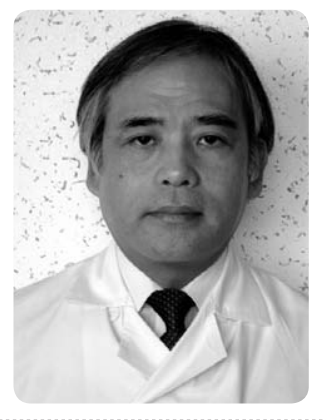

齊 藤 力

Chikara Saito

新潟大学名誉教授

東京歯科大学口腔顎顔面外科学講座

Professor Emeritus of Niigata University

Department of Oral \& Maxillofacial Surgery, Tokyo Dental College

（1）顎変形症治療の歴史

顎変形症の外科的治療を最初に行ったのは米国の Hullihen で, 1849 年に 5 歳時に頸部火傷によっ て生じた 20 歳, 女性の開咬を伴う下顎前突症に対して下顎前方歯槽部骨切り術を行ったと報告して いる。20 世紀初頭から下顎前突症に対して多くの手術法が発表されるようになった。下顎前方歯槽 骨切り法, 下顎頭切除法, 下顎体一部切除法, 下顎枝水平骨切り, 下顎頭頸部の骨切り, 下顎角部骨 切除法などが報告され，Kostečka（1934）は下顎枝斜め骨切り法を発表し，Hunsuck（1968）は口内 法による下顎枝垂直骨切り術を報告している。Obwegeser（1957，1964）は口内法により下顎骨を移 動させる下顎枝矢状分割法を発表し, 現在, 最も多く行われている手術法の1つとなっている。Le Fort I 型骨切り術は von Langenbeck（1859）によって鼻咽腔の腫瘍摘出のために用いて以来，主と して腫瘍切除に適用されていた。本法を顎矯正外科に最初に応用したのはWassmund (1927) で開 咬の修正に利用した。その後Axhausen（1936）, Schuchardt（1942）, Gillies（1957）らによって改 良が加えられ, Obwegeserによって常に安定した結果の得られる標準的手術法となった Obwegeser （1970）は Le Fort I 型骨切りと下顎枝矢状分割法による上下顎移動術を報告している。 McCarthy ら（1992）は下顎骨延長例を報告し，成長期でも顔貌の改善を行うことで患者の心理的障害を排除で きることから，顎変形症治療の選択肢の一つとなっている。

本邦では中村平蔵（1941）が Kostečka 法による下顎後退術を報告したのが最初である。その後, 高橋庄二郎（1971）によって下顎枝矢状分割法が日本に初めて導入されて以来, 顎変形症手術は多く の施設で行われるようになり飛躍的に増加した。しかし 1980 年代までは矯正歯科との連携は行われ ず, 顔面の審美的回復もさることながら, 咬合改善による口腔領域の諸機能の回復が重要であるとい う観点から口腔外科，矯正歯科や歯科基礎の各分野の参加が必要との認識が広まり，1978 年に第 1 回の顎変形症研究会が開催され 1991 年に日本顎変形症学会となり, 2014 年度には 2,000 名を超える 会員数となった。

(2) 本邦における顎変形症治療の現況

2008 年に日本顎変形症学会によって顎変形症治療の実態調查が行われ，189医療施設から回答が得 られた。顎矯正手術施行患者数は 2,926 名で，このうち下顎前突症が 1,977 名と全体の $67.6 \%$ 占め ていた。術前矯正治療期間は平均 11 か月であった。

近年，コンピュータソフトウェアの開発が進み，セファロ分析が正確，かつ容易に行うことができ るようになり, さらにCBCT, MRI, Medical CT, および 3D カメラのデータから三次元的診断, 
治療計画，手術法選択，三次元的治療予測，ならびに三次元実態モデルによる顎顔面形態のビジュア ル化と分析，手術シミュレーションなどが行われるようになり，CAD/CAM システムによる手術用 スプリントの作製も試みられている。また術前の画像情報を解析して正確な手術を補佐するコン ピュータ支援ナビゲーション手術 CAS の研究, 開発も行われている。

(3) 顎変形症治療の今後の課題

患者にとっても, 術者にとっても安全で確実な治療, 効果的な治療法の確立, および患者の負担が 少ない効率的な治療体系の確立である。このためには, より安全で安心な手術を行うための器械や機 材の開発, 経済的, 社会的, 環境的ニーズに呼応したチーム医療の確立, 顎変形症治療に関連する顎 顔面口腔領域の諸機能, すなわち咀嚼, 嚥下, 構音などの口腔機能に留まらず, 咽頭気道形態変化に 伴う呼吸機能, 耳管機能, 通鼻機能, ならびに顎顔面領域の形態に関する三次元的研究, 患者の心理 に関する研究などのさらなる成果が望まれる。一方で顎変形症の治療は, それぞれの専門領域におけ る医療技術，ならびに治療体系を着実に進歩させていくことが重要であり，加えて自己の専門領域以 外の知識と技能を正しく身につけていくことが，より良い結果を得るために重要である。

\section{略 歴}

1972 年 3 月 1976 年 6 月 1976 年 7 月 1977 年 9 月 1993 年 11 月 2001 年 10 月 2001 年 11 月〜

2007 年 4 月〜 2009 年 3 月 2004 年 1 月〜 2011 年 6 月 2013 年 4 月 2015 年 4 月
東京歯科大学 卒業

東京歯科大学大学院歯学研究科（口腔外科学専攻）修了

東京歯科大学 口腔外科学第 II 講座 助手

東京歯科大学 口腔外科学第 II 講座 講師

東京歯科大学 口腔外科学第 II 講座 助教授

東京歯科大学 口腔外科学第 II 講座 教授 新潟大学教育研究院医歯学系 教授

新潟大学大学院医歯学総合研究科 顎顔面再建学講座 組織再建口腔外科学分野 教授 新潟大学医歯学総合病院 副病院長

特定非営利活動法人日本頜変形症学会 理事長

東京歯科大学 口腔外科学講座 客員教授

東京歯科大学 口腔顎顔面外科学講座 客員教授

\section{資格・免許等}

1980 年

（社）日本口腔外科学会認定医制度による認定医（現専門医）（第 23 号）

1986 年

（社）日本口腔外科学会認定医制度による指導医（第 208 号） 